\title{
From Traditional Schools to Modern Schools: The Quest for to Improve the Quality of Schools Environment in Iran
}

\author{
Kimia Ghasemi ${ }^{1}$, Mostafa Behzadfar ${ }^{1} \&$ Mahdi Hamzenejad ${ }^{1}$ \\ ${ }^{1}$ School of Architecture and Environmental Design, Iran University of Science \& Technology, Tehran, Iran \\ Correspondence: Kimia Ghasemi, School of Architecture and Environmental Design, Iran University of Science \\ \& Technology, Tehran, Iran.
}

Received: September 25, 2020

Accepted: February 28, 2021

Online Published: March 3, 2021

doi:10.5539/mas.v15n2p24

URL: https://doi.org/10.5539/mas.v15n2p24

This study was funded by Iran National Science Foundation (INSF) Grant Number (97018482).

\begin{abstract}
This article, through comparison, analyzes evolutions in architecture and school concepts and the relation between them in classic and modern periods in Iran, and by relying on persistent traditional Islamic schools architectural design patterns, provides an atmosphere, conforming to physical and spiritual needs in schools. The research method used in this article is descriptive-analytical and is conducted through library study in order to get familiarized with persistent social components in these schools, to use in new schools. In this research, after evaluating traditional schools, some factors, such as flexibility, central courtyard and the presence of natural elements in there, annular formation of classrooms and appropriate atmosphere for discussions and the transformation process of the interior and exterior relations are introduced which we can use in designing new schools, in order to fully improve the quality of the atmosphere in modern schools.
\end{abstract}

Keywords: educational spaces, traditional schools, contemporary schools, schools environment, Islamic architecture, Iranian architecture

\section{Introduction}

One of the important needs of any society is education. Education, due to playing a greatly important role in mankind's evolution, is of great importance. One type of important educational environments are the schools; schools are an important part of any neighborhood, the people using which are usually the local residents. The flexible design of schools, based on the knowledge of local advantages and disadvantages, through the local residents' help and cooperation, can gradually have a significant impact on the quality of their lives and finally, increase their fixation on their own neighborhood (Pilloton, 2010).

The importance of designing educational environments for improving the learning and education quality is known to everyone nowadays. Many researchers have studied the importance of designing educational environments in education, children's learning, and their growth, in the past years (Thoring, Desmet, \& Badke-Schaub, 2018; K. Fischer et al., 2019; B. Hodson \& A. Sander, 2017; Rivas, Querol, Wright, \& Sunyer, 2018; Henriksen \& Stambulova, 2017; Manahasa, Özsoy, \& Manahasa, 2021; Francis Norwood, Lakhani, \& Kendall, 2021). Understanding how a learning environment, functions effectively, is very necessary for designing an architectural environment. Effective learning environment is an environment, which aside from other effective components in educating children, such as curriculum, teachers and etc. has an important effect in educating children. Although the physical environment of schools is only one of the effective components in learning, it is considered the most important component in an active learning environment (De Gregori, 2007).

Among recent researches in the field of designing educational environments, Nair and Fielding's work, in which they propose patterns for designing educational environments, can be mentioned. In the proposed patterns in this book, the necessity of correlation between interior and exterior, and the importance of interior and exterior views have been emphasized as two important factors in designing educational environments. Living beings are created in a way that naturally needs to have a relation with the outside world and this need is especially seen in younger ages. Therefore, every possibility of having a relationship between the outside and inside world should be used. They also talk about the importance of interior and exterior views in schools: Due to the fact, that most of the 
learning process happens at schools in limited environments, it is essential to broaden the students' perspectives, creating visible lines to outside of the classrooms as much as possible (Nair \& Fielding, 2013).

Some of the documents of this research originate from historical descriptive texts from orientalists and historians. From this time, Chardin (1971) and Kaempfer (1977) are more well-known. On the other hand, texts from Iranian and non-Iranian experts on Iranian schools architecture in the Islamic era are available; among them are: evaluation of schools and their architecture in Islamic lands (Hillenbrand, 2004), Iranian Islamic architecture (Pirnia, 2006), The Timurid Architecture of Iran and Turan (Golombek \& Wilber, 1907), Timurid architecture in khurasan (O'kane, 1987) and History of schools in Iran and the History of schools in Iran since ancient times to the foundation of Dar ul-Funun (Sultanzadeh, 2006).

Based on the aforementioned sources, the historical process of the architectural transformation of schools in Iran, like other architectural functions, can be divided to two main eras: 1 . The era of traditional architecture until Qajar dynasty (820-1925) and 2. The era of modern architecture since the end of Qajar until today (1925-2021) (Ghaffari, 1998).

In the first era, environments have mutual identities and desirable quality and persistent values (Ghaffari, 1998), most of them had environments, which apart from seminary students, everyone could use and therefore, the coherence between these two parts of the society would be strengthened. The existence of such an environment shows us the connection between the school and the city and its placement, shows the quality of this connection (Pirnia, 2006). But in the modern era, by distancing from old architectural values, we have seen a faceless, imitating kind of architecture, which originates from impetuosity, functionalism with no correlation with traditions and Iranian social believes (Ghaffari, 1998).

Therefore, while traditional schools were considered elements of identity and culture of cities by their own individual features and in addition to unity in principles and environmental reform, had significant variety and were constructed according to their own special local circumstances, the dominant pattern in modern schools, without paying attention to functional educational possibilities such as open space, by emphasizing on entertainment and pleasure, as small environments, conforms to patterns of residential landscaping and covered with asphalt, with some limited elements and equipment of games and physical activities (Tahersima, Irani Behbahani, \& Bazrafkan, 2015). Thus, this research, in order to increase the quality of designing educational environments, by relying on persistent patterns of traditional Islamic school designs, wants to provide environments, which meet physical and spiritual needs of students in schools.

\section{Literature Review}

\subsection{Iran Traditional Schools}

After becoming an Islamic government, mosques were one of the first educational environments, where science and Islamic laws were taught (Pasandideh, 2006). Before today's definition of schools, in addition to educational, religious functions, most of the times political-social roles and functions and occasionally conflicts and religious or political animosities and social conflicts happened in schools (Sultanzadeh, 2006).

From the beginning of the fourth and during the fifth century, there have been transformations in Iran's education system. Mosques buildings distanced from their simple forms and classrooms and rooms for students' residence were built in them. Since then until the construction of independent schools, education took place in mosques for years and schools were located inside mosques.

Using mosques as an educational environment was not only due to the nature of religion, but also mosques' serious role as the mainstay of Islamic cities was also important in benefitting from them education-wise. Generally, mosques in the first centuries of Islam were the meeting point of social activities and relations and had three general duties. First, the place for individual or collective worship. Second, mosques were educational environments. Third, mosques were the center of political and social activities. Therefore, mosques were the mainstay of cities. But among this mass of different activities, what was the most emphasized and recommended, was the educational aspect of mosques (SamiAzar, 1997).

In the history of Islam, the correlation between two centers of worship and knowledge, mosques, and schools, has existed in different forms, which from both scientific and spiritual and later, architectural points of view is a topic to be discussed. Mosques being a social and religious base and persistence of religious teaching tradition in mosques and as a result of their mutual functional and cultural aspect with schools, have led to the placement of religious schools, after receiving the necessary identity, next to mosques. Constructing schools next to mosques was only possible if there was an empty space or an expendable building or complex next to the mosque or both the mosque and the school were constructed at the same time; otherwise school would be built with some 
distance from the mosque and connected to the mosque through different means of connection, especially a bazaar (Sultanzadeh, 2006). Merging these two functions and constructing them in the form of one building led to architects imperatively make changes in some conventional and persistent architectural patterns, by combining different functions of two structures, sometimes mutual, which in its own way was a type of innovation in designing environments and environmental combinations (Ghobadian, 2013).

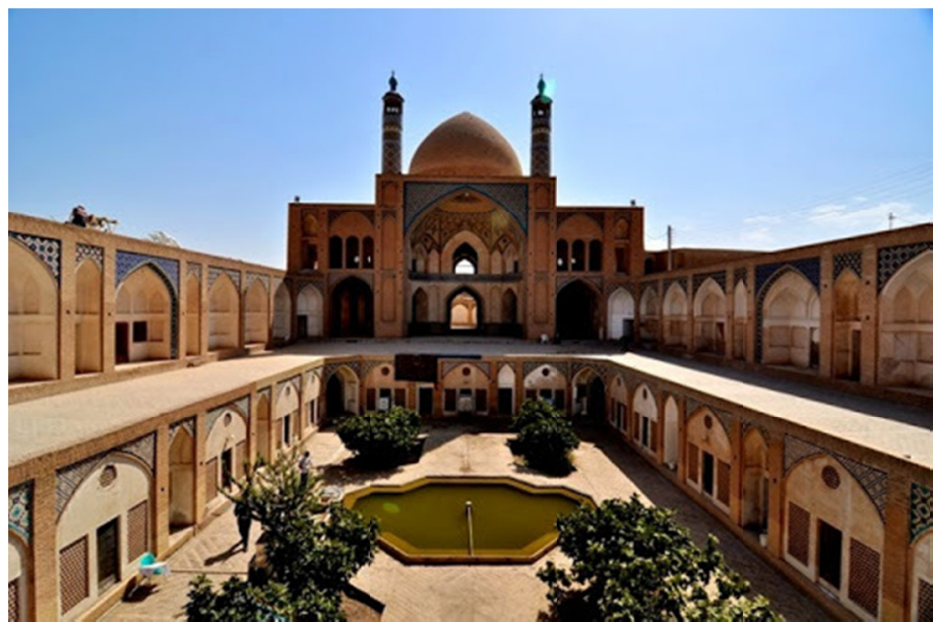

Figure 1. Agha Bozorg Mosque and School in Kashan, Isfahan, Qajar era (1848-1895)

(Combining the functions of school with another important function in cities and transforming the school's environment to a city square for people to gather in order to achieve social goals)

Gradually, with religious sciences progressing and evolving, and the education process becoming longer and the necessity of residence for seminary students, the requirements of having schools were prepared. Location of these schools was around mosques, bazaars, residential areas and sometimes, squares.

The economic and social status of the bazaar and the people working in bazaars, which came from business-productive cities' economic infrastructure, and their connection and relation with social and religious centers, especially with mosques, were the reason that religious schools could as much as possible have a place in bazaars. Location of schools in bazaars, more than anything, tended to be next to mosques and city centers (Sultanzadeh, 2006).

From this time forth, education took place in schools. Schools were located next to mosques and were a source, not only for students but also for the whole society and provided a vase area of services and activities for people.

Further, in Safavid era (1501-1732) education still took place in schools. School buildings were near to or separate from mosques. Schools were a part of society and not separate from it. Building, schools was at its own peak during Safavaid era, that it is said there were fifty-seven schools in Isfahan (Kiani, 2000).

Shia coming to power and Safavid's hold on cultural and though foundations occur at the same time, in a way that it can be said such unity between people and the government can't be seen in many eras. Therefore, schools in Isfahan, became centers for thought exchange and empowering national unity and different methods of different social circles coming together were displayed. Methods, in which school is formed next to the people, on the same level with them and the definition of the borders between social circles were not visual.

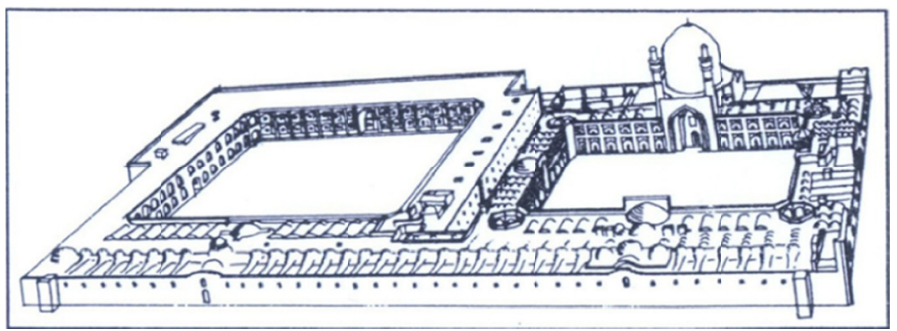



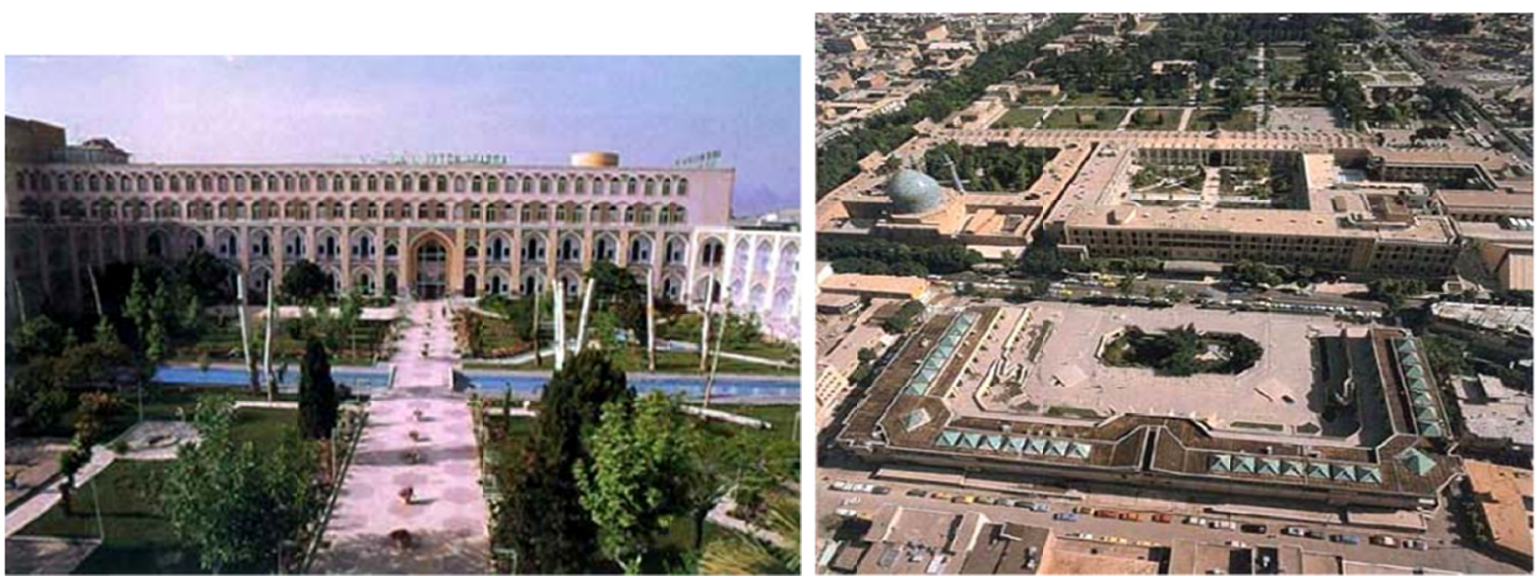

Figure 2. Chaharbagh school and surrounding tissue (Bazaar, caravanserai), Isfahan, Safavid era (1704-1714)

(Pirnia, 2001)

In some schools, people were drawn to schools and therefore, routes people took would be the same as the seminary students' and the existence of many mutual environments, in fact, broadened the connection between these two atmospheres. The development of the education system in this era was accompanied by the relative evolution of schools. Although not many architectural creativity and innovations were brought out. The best model of this architecture can be seen in Shah Sultan Hussein School or Charbagh School (SamiAzar, 1997).

In the Qajar (1795-1925) and Pahlavi periods (1925-1979), the education was done in the schools. The school building was a part of the city but unlike the previous period, it was not related to the mosques. In fact, the schools were separated from society and was not a part of it. The schools in the first Pahlavi period were among the outstanding buildings of the cities, the buildings that were the symbol of governmental architecture more than anything and showed the decision of the government to generate social transformations. The schools that were designed and implemented in this period converted to models that are considered in the construction of small or big schools for years all around the country (Kiani, 2000).
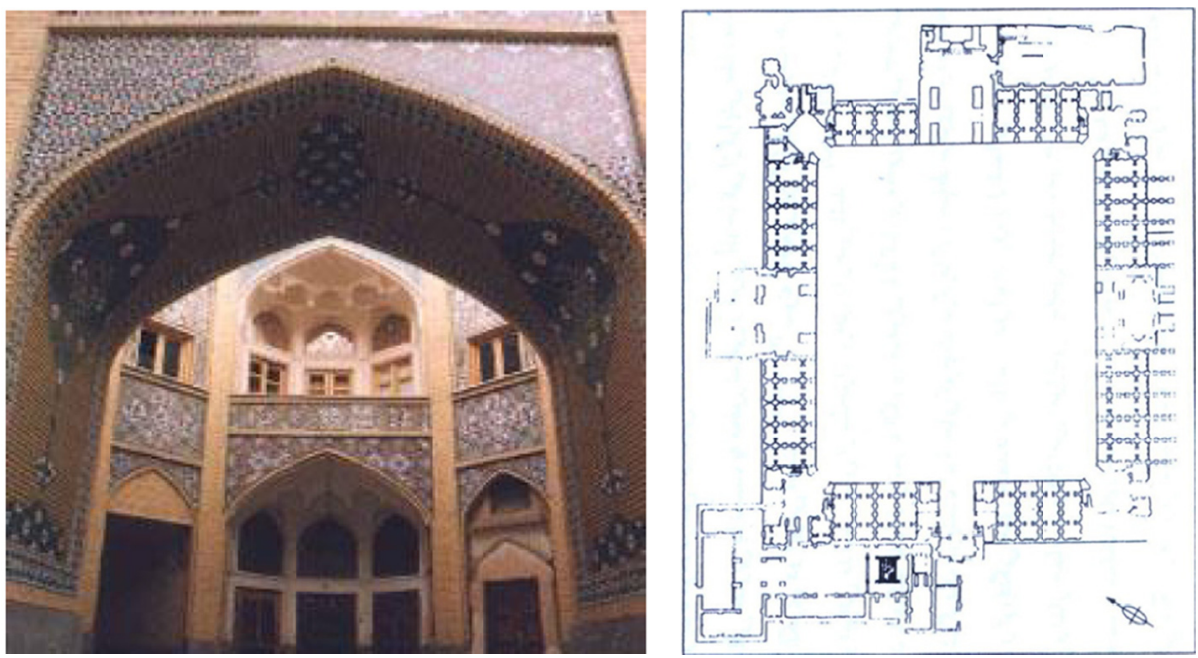

Figure 3. Sadr School in Isfahan, Safavid era (1805-1814)

\subsection{Iran Contemporary Schools}

From the middle of the nineteenth century and following the events of some internal and international reformation, Iran went through a vast political-social transformation. The deepest and most persistent aspect of this transformation was the cultural aspect. And eventually led to disfavor towards the traditional architecture. Reformations in humans' lives in modern times have affected all social organisms, such as the education system. The result of this process was distancing from traditional patterns and increasing approach to an embodiment of western cultures such as using the modern education system.

Modernist tendencies, which had affected the fields of architecture and education, provided the requirements for modern schools to appear. Nowadays, education still takes place in schools. School buildings are part of the 
society but its functions are done independently and have no relation with the society. Schools are separate from society, and not a part of it.

In the first years of the twentieth-century, the circumstance were completely susceptible, and eventually a new season of education came. The new education system had two fundamental features, which extinguished it from the traditional education system: 1- distancing from religious origins, 2-western approach (Alagheband, 2017). School buildings with the traditional pattern were completely put aside and a new form of schools with western architecture came about. Therefore, a new definition of the educational environment and its physical features was formed and designing schools was done based on new principles. The most important reform in the history of constructing schools in Iran was the substitution of hallways instead of central courtyards in the schools of the last century in Iran. These reformations were, in fact, the end of traditional school patterns and the beginning of a new method of designing schools. This reform, in fact, is the disestablishment of concepts of subjectivism, the central courtyard and the traditional hierarchy in the formation of environments in school (SamiAzar, 2000).

The truth is that, through historical and cultural reformations, that led to schools architecture transformation and distancing from traditional patterns, there has not been any deliberate thought about the necessities of a constructive educational environment. With this ideology, the physical environment of the new education system is no different than a container of non-living things and there is no place for dynamic movements in it (SamiAzar, 1997).

Although excellent designs based on the needs of students and adapting the learning environment with new training methods and educational technology have been the task of this institution, severall designs of schools that have ignored the climatic characteristics and style of architecture of a region were constructed by this institution. Most of the school produced by this intuition in different areas and cities with different climates and needs have the same physical shape. The definition of each space in school has no identity, only the classroom is important, because it is the place where learning happens; the courtyard in schools is valued the least. There are no specific differences between the design of public and private, disabled children, and new village schools. They are all patterned after the same classroom based model. They are all patterned after the same classroom based model. This cells and bells model is the common model for controlling children the corridors provide the adults with the most control. Students leaving the classrooms have nowhere to go because the courtyard and the whole building are easily controlled. In schools there are no spaces like the semi open space of the balcony in the old schools. All educational activities are performed only in the classroom, sciences labs and sport halls. In fact the lack of collaboration between architects, planners, employers, parents, teachers and especially the children has led to the same projects to being created without any innovative concepts and ideas in the process of designing (Irvani, 2020).
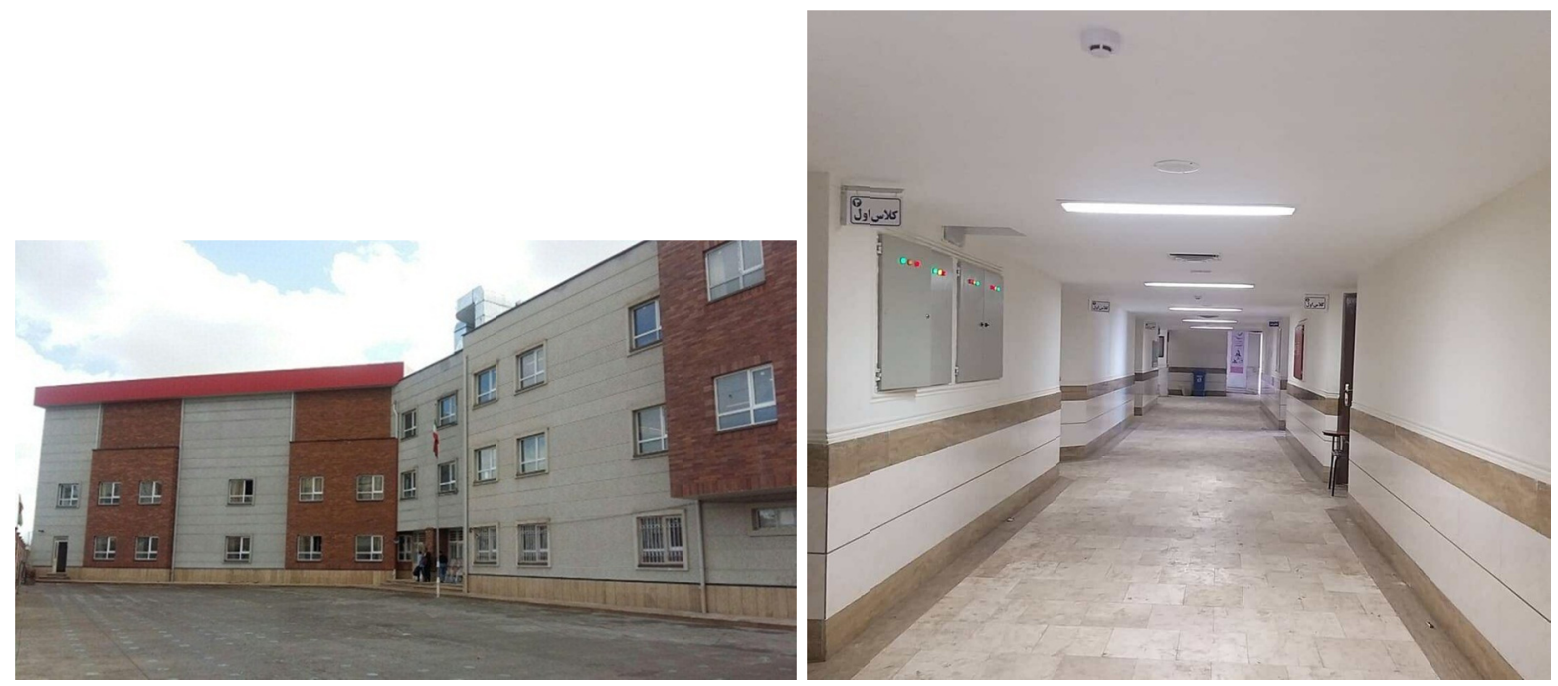

Figure 4. An example of modern schools (Ghasemi, Hamzenejad, \& Meshkini, 2019)

(The architecture of the building is different from that of traditional schools, meaning that, it has a greater tendency to be in shape of a rectangle; in this period, introversion is less welcomed and new structures tend to be more extraverted, and as a result, central courtyards are replaced with linear structures) 
Table 1. The comparison between the traditional and modern school spaces in Iran (Authors)

\begin{tabular}{|c|c|c|}
\hline Elements & Traditional school (820-1925) & Modern school (1925-2021) \\
\hline School's parts & $\begin{array}{l}\text { chamber, classrooms, Shabestan } \\
\text { (praying halls), porch, dome, } \\
\text { courtyard, library }\end{array}$ & Classrooms, hallways, courtyard \\
\hline $\begin{array}{l}\text { Location of functional and } \\
\text { environmental elements }\end{array}$ & 4 directions around the courtyard & Classes in rows along the hallway \\
\hline Using natural elements & Waterscape and green landscape & $\begin{array}{l}\text { Open space without any natural } \\
\text { elements }\end{array}$ \\
\hline \multirow{2}{*}{ Environmental features } & \multirow{2}{*}{$\begin{array}{l}\text { - the close relationship between } \\
\text { the texture around and neighboring } \\
\text { with important centers } \\
\text { - } \quad \text { hosting local residents } \\
\text { - entry in harmony with texture } \\
\text { and proper for passers-by }\end{array}$} & 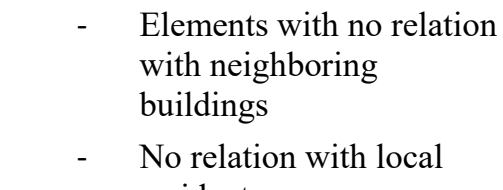 \\
\hline & & $\begin{array}{l}\text { residents } \\
\text { Particular entry with, in } \\
\text { opposition with texture } \\
\text { and no relation with } \\
\text { passers-by }\end{array}$ \\
\hline Function & $\begin{array}{l}\text { Educational, religious, political and } \\
\text { social }\end{array}$ & Educational \\
\hline Relations and access & $\begin{array}{l}\text { Through courtyard, porch, and } \\
\text { stoops }\end{array}$ & Through hallways \\
\hline \multirow{2}{*}{$\begin{array}{l}\text { The relationship between inside } \\
\text { and outside }\end{array}$} & $\begin{array}{l}\text { - being able to be in dome, } \\
\text { porch, chamber, courtyard }\end{array}$ & \multirow{2}{*}{$\begin{array}{l}\text { - Enclosed space of the } \\
\text { classrooms } \\
\text { - Educating directly, regularly and } \\
\text { monotonous and passive students }\end{array}$} \\
\hline & $\begin{array}{l}\text { - appropriate and various spaces } \\
\text { for gathering, discussion and } \\
\text { teamwork }\end{array}$ & \\
\hline \multirow{3}{*}{$\begin{array}{l}\text { Open and semi-open space } \\
\text { function }\end{array}$} & - $\quad$ Education & \multirow{3}{*}{$\begin{array}{l}\text { - } \quad \text { Forming rows and regulating } \\
\text { entry to classrooms } \\
\text { - } \quad \text { Entertainment and sports } \\
\text { - } \quad \text { Not providing access }\end{array}$} \\
\hline & Social and religious & \\
\hline & - $\quad$ Giving access to various spaces & \\
\hline
\end{tabular}

\section{Results}

\subsection{The Principles that Could Be Taught from Iran Traditional Schools}

The reason why we evaluated traditional schools is to achieve persistent architectural principles for the betterment of today's educational environments' designs. By studying and knowing Islamic schools' architecture, we can find out its advantages and use its successful pattern in harmony with today's need and modern methods of designing. Extracting Islamic schools' architectural patterns provides an opportunity for modern architecture to conform to the persistent traditional form of architecture, which would lead to designing desirable modern schools. Of course in the past, the Islamic education system was often teacher-student based and focused more on activities such as discussions and sermons. Therefore, the variety of activities and behaviors at schools was limited. But today, with science advancing and new techniques and methods of education, behaviors at schools have become various. Schools need different open and enclosed spaces, in order to increase opportunities for experiencing and learning. Thus, in formulating modern schools' designing principles, in addition to conforming to persistent Islamic architecture, we should pay attention, particularly to modern educational needs. Some of the Islamic schools' feature will be discussed further.

\subsubsection{Flexibility}

Reformations in the different functions of schools in the Islamic era and the combination of the educational environment with religious, political, social approaches, are proof themselves, that flexibility has been part of the whole fabric and functions of schools during the course of history.

The body of traditional schools' architecture shows that the location of residence and education being the same, living around classmates and schoolmates, mosques being inside schools and using mosques' spaces as a part of 
educational space, would give life, dynamic, and vitality to schools' environments (Yazdanfar, Khanmohammadi, \& Darwish, 2014).

The first and main function of Islamic schools was sermon and discussion; therefore, the columns in Shabestans, benches, and porches in schools have been appropriate elements in forming circles of sermons and discussions. In traditional schools, the evolution of the idea of semi-open spaces, which in different seasons would be used as a place for teaching, and if needed, the courtyard would be connected to it too, is perfectly visible. Using such environments for education benefited from three main traditional education system's features. The porches, due to their own spatial features, seemed appropriate for both of the aforementioned functions. Second, the materials of education and their contents were useful to both high-level students and beginners. Students' participation in some sermons, by choice, which was not necessarily on their curriculum, required a space like porches, so that students could easily gather around or leave. Such function required open and expandable space, good examples of which are porches. Third, schools' environments were not completely closed and did not only belong to students, and people, especially on special religious occasions, could freely participate. Under these circumstances, the courtyard, connecting to the porch, could host the mass of listeners (SamiAzar, 2000).

In a school such as Madar Shah in Isfahan, on one hand due to being not only an educational environment, but also a place of worship, and on the other hand because of waqf documents emphasizing on the environment being public, the environment and functions of the school were not separate from society and social life, but having functions such as caravanserai and bazaar around it also emphasize this point and show the underlying importance of schools as multi-purpose buildings in the texture of the city (Hajebi \& Arzhmand, 2011).

While modern schools' environments have the least relation with open space and are neither expandable nor flexible. Open modern educational space is not capable of delivering an effective and constructive space, which positively affects education. In the modern era, school patterns consist of classrooms organized in rows and monotonous plan of the classrooms, straight-line formations and monotonous placement of windows in the facade and desks in the classrooms and direct, regulated and monotonous method of delivering the lessons, based on the students' passive behaviors, only classrooms can provide the most appropriate circumstances for education. In fact, open space, a landscape without any positive active educational function, is only a place to have discipline at the time of entry or exit, entertainment, getting away from the pressure of education in the classrooms and since movement, dynamic, and enthusiasm, in there, are aimless, it cannot have an educational role or function.

\subsubsection{Central Courtyard and the Presence of Natural Elements in It}

The central courtyard has been a dominant element in most of the Islamic cities (Aminzadeh, 2000). Traditional schools' patterns in Iran show a continuous and active educational function in central courtyards (SamiAzar, 2000). In these schools, courtyard plays a fundamental role in forming spaces and defining students' behaviors, and based on this, creates a garden-like variety in the school's courtyard by using pools, gardens, and trees (Kianmehr \& Taghvanjad, 2011).

Presence of waterscapes and green landscapes in the central courtyard played an important role. Usually, in central courtyards, there are gardens, filled with different flowers and trees, and also pools and small shallow swimming pools, which in addition to illumination, by creating shadows and relatively increasing the humidity (Bonine, 1980), would help improve the conditions in the central courtyard and also would be a natural cooling system. Central courtyards in traditional schools, such as Sultan Hussein school in Isfahan, also known as Madar or Charbagh School has created a great force in creating such vital environment, filled with human interaction, it has been able to turn a school into a social center and higher than that, to human society (SamiAzar, 2000). Creek passing through the courtyard and sycamores in Madar Shah School make this building vital and instill the sense of perambulation throughout the city (Kianmehr \& Taghvanjad, 2011). The most important bodily transformation in the modern era is the substitution of courtyards with hallways. This transformation was, in fact, the end to traditional schools' pattern and the beginning of designing schools in a new way, which has now become a principle in Iran. This transformation, in fact, is the disestablishment of concepts of subjectivism, the central courtyard and the traditional hierarchy in the formation of environments in school. In the schools of the second Pahlavi era (1941-1979), due to using residential buildings like schools, the courtyards in schools turned into an asphalt-covered space with a few sports equipment. 

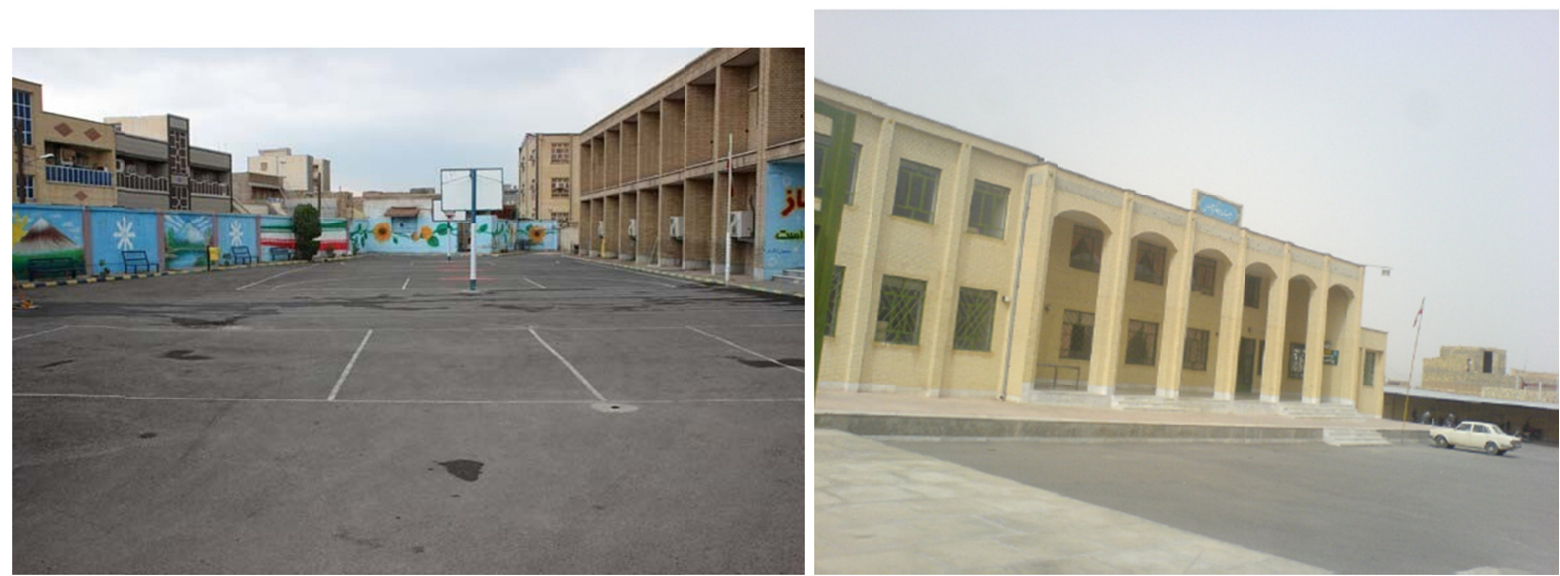

Figure 5. An example of the modern schools' courtyards, is an asphalt-covered space with a few entertainment equipment

Courtyard in modern schools, in opposition with traditional schools, is not supposed to provide students with a happy and spiritual space, and are only defined as open physical space. Therefore, in opposition with traditional schools, where the courtyard was surrounded with the building, in modern schools, the main building is surrounded by neighboring courtyards. This transformation, in fact, is organizing empty and full spaces, which is visible in modern schools. The new discipline, believes that classic education mostly took place inside the building and open and semi-open spaces do not have an important place in it. For such function, an interior hallway, as a connector between spaces, seems more logical than an exterior courtyard and this approach is regularly repeated in designing modern schools (SamiAzar, 2000).
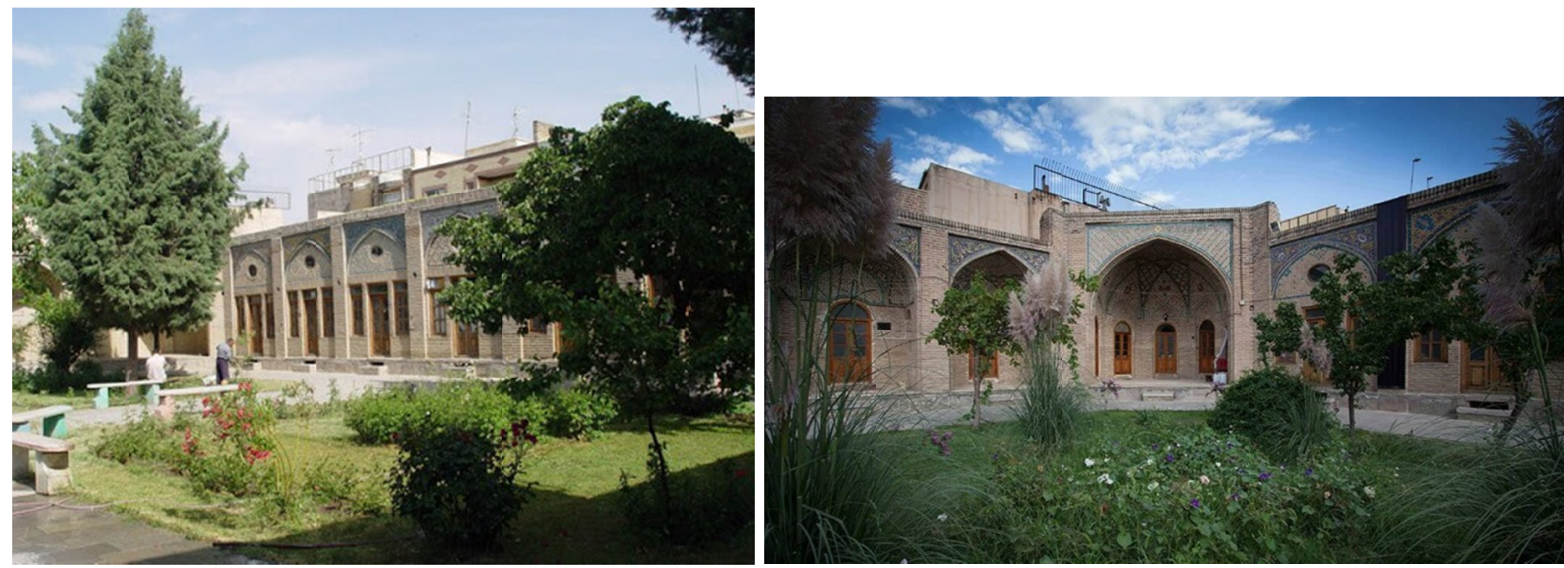

Figure 6. Presence of waterscapes and green landscapes in traditional schools' courtyards, Sheikh ul-Islam

\subsubsection{Annular Formation of Classrooms}

The traditional system, in which students would sit in circles, is a process based on the discussion (Rezaei Esfahani, 1997). Discussion considers education a process, which is based on people's action and reaction, which by simplification of learning, leads to better skills and knowledge transfer and generalization. Since courtyard and porches in traditional schools could very well provide appropriate and various spaces for people to gather together, the possibility to have discussions and encourage teamwork played an educational role. This method of teaching, instead of being teacher-based like modern method, was formed based on students' activity and teamwork, and perhaps it is safe to say, that one of the important factors in students' educational progress was this method of teaching, called Circle. Reasons for using this method can be named as such: physical limitations of education, subjective character of the form of circle and emphasis on multi-aspect discussions and group discussions (Khosrowjerdi, MokramDoust, \& Zoghi, 2012).

Since mid-Qajarids era, the encounter between modernity and traditions immediately was drawn to education. Among pioneers of modern education, Mirza Hassan Rushdie tried the most. He brought up two important topics in modern education, which still persist to this day: 1. New classroom environment and its formation, in straight rows of students (Kasravi, 1965) and 2. Learning based on spelling alphabet (Roshdiye, 1983). But this 
transformation eventually led to a general method of teaching, by teachers' demonstration and explanation, in which students would sit in front of the teacher and would rarely be asked to participate actively (Sadiq, 1931). Therefore, the answering method replaced circle and group discussion method and what was happening was all based on memorization. Since the materials in this method would be received through only two channels of vision and hearing, therefore the physical educational space can only be a closed space, such as a classroom in its common form (SamiAzar, 2000).

\subsubsection{The Process of Transformation of Inside and Outside Relation}

In the past most of the schools in Iran were formed following the subjective pattern of the central courtyard, which is surrounded by two-story porticos and behind these porticos, there were students' rooms. Four semi-open porches also with taller arches on four sides of the courtyard would be used for gathering together for speeches and discussion circles. This pattern provided a calm environment for teaching and studying, and at the same time creating a strong and effective relationship between the closed space and the courtyard, using semi-open spaces (Azemati, Aminifar, \& Pourbagher, 2016).

The relation between open and semi-open spaces in Iranian schools during Safavid's era, led to efficient relation between education and nature; in which, porches and stoops in front of chambers, were some of the effective factors in forming this relationship and made access to open space possible, created flexibility and the opportunity for social interactions. These interactions, which were in harmony with Iranian culture, were the cultural transferring factors to users. According to the relationship between education in traditional Iranian schools and body of space, the placement of open and enclosed space next to each other played an effective and active role in improving the quality of the educational environment, variety, flexibility, and increasing social interactions. Porches, as an intermediate space between courtyards (garden) and classrooms and chambers, were a safe haven for interactions and information transfer in schools, are also of importance. As a result, it can be said that in Iranian schools, educational environment and courtyard played an important role in transferring local culture.

In the modern era, the emphasis of designs is mostly on empty spaces in schools; in a way that today, there is an addition to school buildings, called courtyard, but this courtyard does not carry any educational responsibilities and is not a part of classrooms and there is no special curriculum defined for it. In fact, the school's courtyard is merely a place for entertainment and regular learning takes place in classrooms, which is a result of conservative ideology of teaching and has three feature: considers games a non-educational activity and as a result considers courtyard an entertainment environment, strong emphasis on the entertainment aspect of school's courtyard, and extreme emphasis on the element of discipline during the process of education (SamiAzar, 2000).

\section{Discussion and Conclusion}

The current problem of our schools, is the lack of spatial quality in their architecture and substitution of other elements, in comparison with traditional schools. This means in the modern architecture of schools, qualities seen in traditional schools, are not present and instead other elements have replaced them. Nowadays, the education system in our country mostly can be realized in the inner environment and following this, education certainly takes place in an enclosed space. This certainty in historical traditions of educational environments is not seen often.

Architectural pattern of modern schools consists of straight rows and monotonous plan of classrooms, monotonous rows of windows in the façade and straight and monotonous rows of desks in the classrooms and combination of parallel rows, which form the image of a series of straight lines to move between them, which naturally creates a space, which is not only unattractive and not interesting to children, but also is dull and frustrating for them (SamiAzar, 1997). Basically, linear rows are opposed to the students' spiritual conditions. In traditional classrooms, where students' chairs were put in an orderly fashion in front of each other and the teacher's desk was put in front of the class, everyone's focus was on the teacher and the relation between students was limited. This discipline and arrangement, while the teacher is teaching something to the whole class, might be favorable, but ruins the opportunity to learn from classmates and have teamwork (Zeinali Dehshiri, 2010).

On the other hand, courtyards in modern schools, in opposition to traditional schools, neither have central location nor are the heart of the school. In fact, the courtyard is an entertainment environment, which separates the school building from the neighboring buildings and therefore, by no means is a positive space with an active function. Modern education system mostly takes place inside the building and the courtyards are neither a happy space with trees, flowers, and garden nor any educational activity takes place there. In fact, the courtyard is a place to get away from the pressure of education in the classrooms and probably a place, to control and instill 
discipline during entry and exit. Therefore, the courtyard is not at all considered an educational environment and no equipment in there is allocated for education (Radmard \& Saremi, 1996).

What nowadays is used as educational environment patter for the body of schools has no advantages or progress, compared to the first experiences during the past century, therefore, current architecture of our schools is as far away from origins and traditional values, as from creative and progressive understanding about educational environments. Before the appearance of these patterns, architecture, and education system, especially during Safavid's era, were so powerful and advanced, that can be considered as the most complete and coherent idea of general education in Iran (SamiAzar, 2000).

Unfortunately, in most school buildings, users' needs are not paid attention to. This lack of attention has negative effects on the users and interrupts the process of growth and learning. If the arrangement of the school is formed based on the student's needs, the conditions for individual and collective learning will be met. On the other hand, designing favorable schools should be based on persistent architecture. Since the relation between traditional and modern architecture is almost lost, it is essential that by finding Islamic architectural principles and using them in designs, give life to persistent architectural traditions again. Thus, using patterns in traditional Iranian schools architecture along with modern educational discoveries about natural environments' possibilities can lead to the betterment of these places for different educational goals for children.

\subsection{Effects of Designing and Constructing Traditional Schools on the Quality of the Educational Environment They Can Provide for Modern Schools}

- Taking people's needs and closeness between society and schools into consideration: the fact that bazaar was what held the city together and schools were built in the bazaar, is the important secret of people of knowledge close to the people and their livelihood needs. Students and teachers directly and daily interacted with people and directly answered their needs.

- Schools financing by people: the collective need of people and school and locational cohesion was the reason that school's finances were covered through the bazaar. While if this relationship did not exist, education would not survive and would not grow.

- Different methods of its modern realization: nowadays the need for cohesion in science, industry, and business, more than before, shows that one of the priorities of the evolution of science is its site selection in the fields of industry and business.

4.2 Bodily Patterns of Traditional Schools in the Betterment of the Quality of Persistent Social Schools and the Study of the Feasibility of Modern Patterning from Them

- Different bodily arrangements for underlying students' social unity and scientific synergy, instead of destructive competition. Emphasis on general space through central courtyard pattern and small alleys in front of students' rooms encouraged discussion and communication between students.

- Nowadays in designing educational environments, sometimes, due to wrong policies about local peace, mutual social spaces have become mostly places for moving through and individualism is preferred over collectivism. General place, when located in space according to naturalistic emphasis, provides required conditions to attract viewers from neighboring residential and educational spaces. Also the combination of educational and residential and worship environments next to each other, provides the required conditions for students in all fields to coexist, which in some new educational centers have not been given the necessary attention but can lead to strengthening universality among students.

\section{References}

Alagheband, A. (2017). The Sociology of Education. Tehran: Farvardin Library. (In Persian)

Aminzadeh, B. (2000). Wisdom Contact Nature in Muslim Cities. Soffe, 10(31), 40-53. (In Persian)

Azemati, H. R., Aminifar, Z., \& Pourbagher, S. (2016). Spatial Layout Pattern of New Schools based on the Principles of Islamic Schools, to Improving Students Learning. Naqshejahan-Basic studies and New Technologies of Architecture and Planning, 6(2), 16-23. (In Persian)

Bonine, M. E. (1980). Ridity and Structure: Adaption of Indigenous housing in central Iran. In Kenneth Clark \& Patricia Paylore, Desert Housing. University of Arizona.

Chardin, J. (1971). Sir John Chardins Travels In Persia. Argonaut.

DeGregori, A. (2007). Learning environments: redefining the discourse. Thesis for Master of Science in architecture, New Jersey: New Jersey school of architecture. 
Fischer, L. K., Brinkmeyer, D., Karle, S. J., Cremer, K., Huttner, E., Seebauer, M., Nowikow, U., Schütze, B., Voigt, P., Völker, S., \& Kowarik, I. (2019). Biodiverse edible schools: Linking healthy food, school gardens and local urban biodiversity. Urban Forestry \& Urban Greening, 40, 35-43. https://doi.org/10.1016/j.ufug.2018.02.015

Francis Norwood, M., Lakhani, A., \& Kendall, E. (2021). Teaching traditional indoor school lessons in nature: The effects on student learning and behavior. Landscape and Urban Planning, 206, 103963. https://doi.org/10.1016/j.landurbplan.2020.103963

Ghaffari, A. (1998). Principles and Fundamentals of Educational Space. Tehran: Renovation and Equipping of Schools. (In Persian)

Ghasemi, K., Hamzenejad, M., \& Meshkini, A. (2019). The livability of Iranian and Islamic cities considering the nature of traditional land uses in the city and the rules of their settlement. Habitat International, 90, 102006. https://doi.org/10.1016/j.habitatint.2019.102006

Ghobadian, V. (2013). Theories and styles in contemporary Iranian architecture. Tehran: Elme Memar Royal. (In Persian)

Golombek, L., \& Newton Wilber, D. (1907). The Timurid architecture of Iran and turan. Princeton University Press.

Hajebi, B., \& Arzhmand, M. (2011). The Effects of Vaghf (Endowment) on Sustainability of Safavid Madrasas (Schools). Architecture and urban planning, 3(6), 89-102. https://doi.org/10.30480/aup.2011.174

Henriksen, K., \& Stambulova, N. (2017). Creating optimal environments for talent development: A holistic ecological approach. Routledge. https://doi.org/10.4324/9781315668017-19

Hillenbrand, R. (2004). Islamic architecture: form, function, and meaning. Columbia University Press.

Hodson, C. B., \& Sander, H. A. (2017). Green urban landscapes and school-level academic performance. Landscape and Urban Planning, 160, 16-27. https://doi.org/10.1016/j.landurbplan.2016.11.011

Irvani, S. (2020). History of school architechture in Iran. Retrieved from https://www.designshare.com/images/History_of_School_Architecture_in_Iran.pdf

Kaempfer, E. (1977). Am hofe des persischen grosskonigs 1684 - 1685. Deutsch.

Kasravi, A. (1965). History of the Iranian Constitutional Revolution. Tehran: Amir Kabir. (In Persian)

Khosrowjerdi, N., MokramDoust, H., \& Zoghi, E. (2012). A reflection on the designation alphabet in elementary education spaces. Tehran: Tahan. (In Persian)

Kiani, M. Y. (2000). Architecture of Iran: The Islamic Period. Tehran: The Organization for Researching and Composing University Textbooks in the Humanities (SAMT). (In Persian)

Kianmehr, Ghobad, \& Bahare Taghvanjad. (2011). The comparative study of Chaharbagh school of Esfahan tile inscriptions and the beliefs in Safavid era. Historical researches, 47(2), 133-154. (In Persian)

Manahasa, O., Özsoy, A., \& Manahasa, E. (2021). Evaluative, inclusive, participatory: Developing a new language with children for school building design. Building and Environment, 188, 107374. https://doi.org/10.1016/j.buildenv.2020.107374

Nair, P., \& Fielding, R. (2013). The Language of School Design: Design Patterns for 21st Century Schools. Designshare.

O'kane, B. (1987). Timurid architecture in khurasan (Islamic art and architecture). Mazda Pub.

Pasandideh, M. (2006). Khorasan Seminary. Mashhad: Islamic Research Foundation. (In Persian)

Pilloton, E. (2010). Teaching Design for Change. North Carolina: Educational facilities in Australian Communities, Unesco.

Pirnia, M. K. (2001). Styles of Iranian Architecture. Tehran: Memariyan. (In Persian)

Pirnia, M. K. (2006). Acquaintance with Islamic Architecture of Iran. Tehran: Soroush Danesh. (In Persian)

Radmard, T., \& Saremi, A. A. (1996). Enduring Values in Iranian Architecture. Tehran: National Heritage Organization. (In Persian)

Rezaei Esfahani, M. A. (1997). Styles of Teaching and Training in Seminaries. Qom: Bustan-e Ketab. (In Persian) 
Rivas, I., Querol, X., Wright, J., \& Sunyer, J. (2018). How to protect school children from the neurodevelopmental harms of air pollution by interventions in the school environment in the urban context. Environment International, 121, 199-206. https://doi.org/10.1016/j.envint.2018.08.063

Roshdiye, S. (1983). Savaneh-e Omr. Tehran: Tarikh-e Iran. (In Persian)

Sadiq, I. (1931). Modern Persia and Her Educational System. New York: Colombia University.

SamiAzar, A. (1997). History of School Change in Iran. Tehran: Organization of the renovation, development and equipping of schools.

SamiAzar, A. (2000). The concept and function of open space in open schools and traditional. Soffeh, 10(31), 104-111. (In Persian)

Sultanzadeh, H. (2006). The history of Iran schools from the ancient era to establishment of Dar ul-Funun. Tehran: Agah. (In Persian)

Tahersima, S., Irani Behbahani, H., \& Bazrafkan, K. (2015). Determining of educational role of Iranian school open spaces regarding the comparative investigation on traditional vs contemporary school (case studies: Chaharbagh, Darlolfonoun and Alborz schools). Reasearches in Islamic Architecture, 3(1), 55-67. (In Persian)

Thoring, K., Desmet, P., \& Badke-Schaub, P. (2018). Creative environments for design education and practice: A typology of creative spaces. Design Studies, 56, 54-83. https://doi.org/10.1016/j.destud.2018.02.001

Yazdanfar, A., Khanmohammadi, M. A, \& Darwish, M. (2014). Responding the psychological needs of human in educational spaces using the lessons from traditional schools. Researches in Islamic Architecture, 1(4), 47-59. (In Persian)

Zeinali Dehshiri, A. (2010). Beautiful school. Master of Elementary Education, Tehran: Allameh Tabatabaee University. (In Persian)

\section{Copyrights}

Copyright for this article is retained by the author(s), with first publication rights granted to the journal.

This is an open-access article distributed under the terms and conditions of the Creative Commons Attribution license (http://creativecommons.org/licenses/by/4.0/). 